\title{
Reregulated Non-accessory Lien in the New Hungarian Civil Code
}

\author{
BALÁZS BodZÁs *
}

\begin{abstract}
The new Civil Code, which entered in force in 2014, contained certain provisions on the accessory lien. since 2014, however, the changing economic conditions required the amendment of the Civil Code. In 2016 the and non-accessory lien was re-introduced into the Hungarian legal system. The reason for the amendment was to enhance the debenture bond market and to make refinancing more secure. The amendment tries to preserve the negotiability and the flexibility of the non-accessory lien and provides increased protection for the pledger (the owner of the object of the pledge). The article explains the nature of the non-accessory lien in a comparative context and clarifies the reasons of its reintroduction in Hungary.
\end{abstract}

Keywords: non-accessory lien, mortgage bond, refinancing loan, mortgage contract, security agreement, transferability of independent lien, right to satisfaction, termination of independent lien

\section{THE PROBLEM}

Lien is an accessory collateral in rem in most European jurisdictions. However, some jurisdictions also recognise the non-accessory form of lien. The different forms of nonaccessory lien have developed in German law (Grundschuld) ${ }^{1}$ and in Swiss law (Schuldbrief) $^{2}$ and, Hungarian private law, pre-World War II, already recognised and regulated non-accessory mortgage (land charge/telekadósság). ${ }^{3}$ This article, however, is limited to the introduction of the reregulated non-accessory lien in the new Hungarian Civil Code.

Various considerations raised during the drafting of the new Hungarian Civil Code, particularly based on dogmatic law, led to a decision that the institution of non-accessory form of mortgage should cease to exist. Prior to the drafting, a long debate of the legal

* Head of Center for Finance and Economics at the Corvinus University of Budapest (Hungary) balazs.bodzasi@uni-corvinus.hu

1 On 'Grundschuld' see more in detail at Gaberdiel and Gladenbeck (2008), Clemente (1999)

2 On 'Schuldbrief' see more in detail at Wehrens (1988) 181-91., Handkommentar zum Schweizer Privatrecht (2007) 968-1080.

3 The arguments for recognising the non-accessory form of mortgage are basically economic in nature: the legislative measures taken to mitigate the impacts of the lending crisis were an important means to recover from the post-World War I economic collapse. Many regulations created in the 1920 s were designed to enable simpler and cheaper access to credit. Among these laws, Act XXXV of 1927 on Mortgages (hereinafter 'Mortgage Act') stands out. The Mortgage Act regulated the nonaccessory form of mortgage, including land charge. The introduction of the land charge (telekadósság) was also motivated by legislators' intention to improve the conditions of access to credit. Following the political changeover, Hungarian legislators were inspired by similar economic policy considerations. 1996 brought sweeping amendments to Civil Code provisions on lien so as to align them to the conditions of the market economy. The institution of non-accessory lien - known as independent lien - re-appeared in Hungarian law. In the next 15 years, independent lien would become deeply nested in Hungarian private law and fulfilled an important role in the functioning of the domestic market of bank refinancing. For more details see Bodzási (2016c) 218-37. 
scholars took place. ${ }^{4}$ It would go beyond the aim of the paper to introduce the details of this debate, however, the supporting reasoning in favour of the non-accessory form of mortgage did not convince the draftors of the new Hungarian Civil Code. Accordingly, Act V of 2013 on the Civil Code (hereinafter the Civil Code), which entered into force on 15 of March 2014, only regulated the accessory form of mortgage - the Civil Code determined the concept of lien as a right to accessory value in rem. Another important change affecting collaterals in rem was the declaration of prohibition against the use of fiduciary collaterals (Section 6:99 of the Civil Code). ${ }^{5}$

Importantly, the revised regulatory concept of the Civil Code referring to collaterals in rem, including lien, seems to make sense from the perspective of dogmatic law. While the basic design of mortgage provisions attracted much criticism, the regulations enshrined in the Civil Code admittedly followed coherent logic.

The main problem was that the Civil Code was adopted after 2008 during a period when the Hungarian economy was still struggling with the negative impacts of the everdeepening financial and lending crisis. In particular, small and medium-sized enterprises found it increasingly difficult to obtain bank loans but the entire Hungarian economy was hit by the credit crunch and a sharp decline in domestic financial sector lending. It was against this economic and financial background that the Civil Code took effect and did away with formerly well-established legal institutions in domestic corporate lending, such as fiduciary collaterals, independent lien and lien on property. It is now clear that such a drastic transformation of regulation under private law has not made the situation of domestic businesses and their access to credit any easier.

The abolishment of non-accessory or independent lien was not one of the most important problems. The drafters of the Civil Code were aware that a sudden shift to using classic accessory mortgage as a result of abolishing independent lien would cause dysfunctionality in the issuance of domestic mortgage backed securities and the closely related bank refinancing market as these branches of the financial sector had been relying on non-accessory, or independent, lien for nearly fifteen years. Therefore, the Civil Code created a special form of lien known as 'separated lien'.

The main feature of separated lien lied in allowing the lienor to transfer accessory mortgage on one occasion ${ }^{6}$ and thereby, accessory lien could be separated from the original secured claim once. The economic purpose of the separation was to enable the same accessory lien to secure another claim concurrently. This other claim burdened the original lienor as opposed to the new lienor acquiring the mortgage as separated lien. However, the new lienor did not enter into a direct relationship with the lienee. In addition, this arrangement had several shortcomings. Separated lien of an accessory nature could not, therefore, fulfil the same role that was formerly fulfilled by independent lien. The use of separated lien caused uncertainty in the Hungarian financial sector and in 2015, the need to reregulate independent lien arose which ultimately led to the amendment of the Civil Code in $2016 .^{7}$

${ }^{4}$ For more details see Bodzási (2010) 365-98., and also Gárdos and Csizmazia (2010) 399422.

5 About the so-called fiduciary securities and about their prohibition see more in detail at Bodzási (2016a) 37-44.

${ }^{6}$ On the various types of lien see Bodzási (2016b) 766-76

${ }^{7}$ For arguments against the re-regulation of the independent lien, see Gárdos (2016) 5. 


\section{CIRCUMSTANCES DETERMINING THE REREGULATION OF INDEPENDENT LIEN}

Two important items of legislation need to be highlighted separately in connection with the reregulation of independent lien:

- Regulation (EU) No. 575/2013 of the European Parliament and of the Council of 26 June 2013 on prudential requirements for credit institutions and investment firms and amending Regulation (EU) No 648/2012 (hereinafter 'CRR Regulation'); and

- Decree No. 20/2015 (VI. 29.) by the National Bank of Hungary (hereinafter NBH Decree) on the forint maturity match of credit institutions.

Article 402 (3) of the CRR Regulation directly applicable in EU member states specifies non-accessory independent mortgage liens in relation to minimising exposure resulting from mortgage lending. This alone encouraged Hungarian legislators to reregulate independent lien. ${ }^{8}$

However, an even more compelling argument was the uncertainty arising under the CRR Regulation as regards the assessment of separated lien, created by the Civil Code as it was unclear whether domestic mortgage lenders could invoke the CRR Regulation's clause on exemptions from 'limits to large exposures'9 in applying separated lien. Invoking the exemption clause of the CRR Regulation for the purposes of providing mortgage loans to financial institutions they refinanced, secured an important competitive advantage for mortgage banks. The CRR Regulation does not recognise the concept and institution of separated lien, which used to be an accessory mortgage arrangement. Accordingly, mortgage banks applying separated lien in their refinancing activities were running the risk of violating the 'limits to large exposures'.

The need to introduce another item of legislation, namely Decree No. 20/2015 (VI. 29.) by the National Bank of Hungary, arose after the compulsory conversion of long-term foreign currency-denominated consumer mortgage loans into HUF, ${ }^{10}$ which resulted in the need of Hungarian banking sector to secure stable long-term HUF resources. As the term to maturity of the overwhelming majority of consumer mortgage loans converted to HUF was over 10 years, a maturity mismatch between mortgage loans and deposits gave rise to a systemic risk, due to deposit-financed lending. This arose because banks had no other option after HUF conversion than to finance their existing mortgage exposures from deposits placed with them. The National Bank of Hungary intended to manage the resulting liquidity risk by requiring banks to secure stable funding in HUF.

Decree 20/2015 (VI. 29.) provides that banks are required to secure stable HUF resources up to $15 \%$ relative to their total mortgage exposures. They are also obliged by the Decree to comply with this requirement in respect of existing mortgage loans. Thereby, the

8 Some Hungarian scholars opine that the CRR Regulation, however, does not contain a direct obligation of implementation. See Gárdos and Vékás (2016). It is still questionable whether the Hungarian financial institutions are eligible for the preferential treatment ensured in the CRR regulation because of the newly re-regulated independent lien. On this issue see Gárdos and Vékás (2016). We believe that Hungarian financial institutions are definitely eligible when dealing with the re-regulated independent lien because the independent lien can be independently transferred.

9 Based on this, the exposure of an institution falling under the CRR Regulation to another institution must not exceed $25 \%$ of its eligible capital.

10 Mandatory conversion to HUF was laid down by Act LXXVII of Act LXXVII of 2014 on the settlement of matters relating to the currency conversion of certain consumer loan agreements and to interest rate rules. 
Decree prescribes the duty to engage adequately stable resources to cover the financing of long-term retail mortgage loans.

The NBH Decree seeks to strengthen the Hungarian banking system by ordering banks to cover long-term assets with long-term liabilities. Reducing the mismatch between maturities in this manner encourages banks to finance their exposures by issuing mortgage bonds or from refinancing loans secured by mortgage bonds rather than from deposits as the former two are recognised as long-term liabilities. Criteria laid down in the Decree are, at present, only met by mortgage bonds and refinancing resources obtained from mortgage banks. All this can also reduce the costs of domestic credit institutions since the interest on mortgage bonds and refinancing loans tend to be lower than the costs of funds used at present. Thereby, price competition in the mortgage loan market can increase, which can in turn improve the availability of funds and increase lending volumes.

The need to reregulate independent lien appeared as separated lien was not an adequate form of security in relation to the transactions the NBH Decree identified as desirable.

The amendment of the Civil Code in respect of lien has been most influenced by economic policies designed to stimulate the mortgage bond market. It was to this end that the National Bank of Hungary issued Decree No. 20/2015 (VI. 29.) on the forint maturity match of credit institutions. As a consequence of this decree, three new actors appeared in the domestic mortgage banking market in $2016 .{ }^{11}$

\section{REREGULATED INDEPENDENT LIEN}

\subsection{The concept of independent lien}

The reregulation of independent lien aimed to facilitate the implementation of economic policy objectives previously outlined. This step is enshrined in Section 11 of Act LXXVII of 2016 on amending Act V of 2013 of the Civil Code (hereinafter CCAA), which took effect on 01 October 2016. The new legal definition reads as follows: 'Mortgage may also be established on real property for the benefit of a financial institution in such a manner that it encumbers the mortgaged item independently of the claim secured, up to a certain amount (independent lien).'

Clearly, the reregulated concept of independent lien substantially differs from that refereed to with the same term in the former Civil Code. An important difference lies in the limitation of the range of lien holders to financial institutions as lienors. Independent lien can only be established in favour of and transferred to a financial institution.

There is no such restriction on the lienee's side, i.e., any entity can be a lienee under an independent lien and accordingly, consumers can also be lienees in respect of independent lien.

Another important change, compared to the provisions of the former Civil Code, is that independent lien can only be established or created in the form of mortgage on real property. This occurs because the legislator claims that the land registry is the only existing vehicle that provides the level of security critical to protecting the lienee as owner. Apart from that, economic actors do not need options to establish other types of lien in nonaccessory form in addition to mortgage on real property. Hence, except for mortgage on real property, all other types of encumbrance (pledges, bailments or chattel mortgage) can be established exclusively as accessory lien. 
After reregulation, independent lien contains an important conceptual element, notably that it encumbers the hypothecated asset (real property) independently of the secured claimeven if a secured claim exists in the case of an independent lien, its legal fate is independent of the legal fate of the independent lien. ${ }^{12}$ Independence in this respect in tantamount to the absence of statutory accessoriness and its attendant legal consequences. The virtue of this independence allows independent lien, in principle, to be created and transferred without a secured claim and may even survive the termination of the claim. From a legal aspect, the reregulated form of independent lien, also known as 'security-oriented' independent lien (independent lien tied to a security purpose) also remains independent of the secured claim. The situation is naturally different from a financial perspective as in practice independent lien is also linked to a secured claim and independent lien without a secured claim, known as isolated independent lien, is therefore irrelevant.

With independent lien, independence also means that the legal grounds or legal relationship underlying the secured claim does need not be specified either in the mortgage contract or in the real estate register. Consequently, legal independence also means being independent of legal title. This, among other things, is an important feature of independent lien from the perspective of securitisation. That is because in the event of securitisation, not having to specify the legal grounds or legal relationship underlying the securitised claim when entering independent lien in the real estate register is a great advantage, which can further increase the financial significance of independent lien in the future.

\subsection{The requirement to define an amount}

Subject to Section 5:100 (1) of the Civil Code, independent lien encumbers the liened item up to a certain amount (independent lien). The lienor is only entitled to satisfaction from the liened item up to this specific amount.

Therefore, the question arises as to the exact meaning of the term 'certain amount'. The point of the question is to ask whether this certain is interpreted to include charges, or whether it only means a certain amount of principal in addition to which the lienor may also claim interest and other charges.

The view of the author is that 'certain amount' refers to a framework amount that includes both principal and related charges (interest and enforcement expenses). It is, therefore, similar in nature to the framework amount referred to in Section 5:98 (3) of the Civil Code up to which (accessory) lien secures the principal and related charges. With accessory mortgage, this framework amount applies to the secured claim and its charges. ${ }^{13}$

Thus, interpreting 'certain amount' as a framework amount means that the lienor can exercise its right to satisfaction up to that amount. This interpretation also governs cases where the amount of the secured claim, in the wording of the Civil Code: the claim as per the security agreement or the claim which may be satisfied from the liened item as per the security agreement, (and its charges) might exceed this amount. Consequently, the lienor may not claim more from the lienee even if the amount as per the security agreement (and its charges) exceeds a certain (framework) amount, which is also entered in the real estate register.

12 The main characteristic of the independent lien is its independence from the secured claim. See Gárdos and Vékás (2016).

13 Gárdos and Vékás regard the amount defined in the lien contract as framework amount. See Gárdos and Vékás (2016). 
When determining the amount in the mortgage contract, or on the basis thereof, in the real estate register, it is of course possible for this amount to cover not only the principal but also its charges. That would, however, oblige the lienor as lender to calculate the amount up to which satisfaction can be sought from the liened item in advance for the entire duration of the loan. This amount can be determined in several ways. It is, however, a requirement that calculation of the secured debt and its charges, if any, taken together should produce an amount that may be entered in the real estate register. Independent lien only ensures coverage up to the registered amount.

In respect of exercise by the lienor of its right to satisfaction, the lienor setting and entering in the real estate register a higher amount than the actual claim does not harm the lienee's interests. That is often the case with accessory mortgage because the lienee's liability is limited to the amount of the actual debt. It follows that the lienee may only be demanded to pay under independent lien the higher of the actual amount of debt and the amount specified in the real estate register (and in the mortgage contract).

If, by creating independent lien, the legislator wished to allow the lienor to obtain satisfaction from the liened item beyond the amount entered in the real estate register and also use it to cover related charges, the Civil Code should contain a separate provision to that effect. Section 5:100 (1) of the Civil Code refers to an 'amount' (certain amount), rather than a 'framework amount' and the Decree text should still mention specifically the option to use the liened item as lienee's liability out of which interest and other charges may also be covered. ${ }^{14}$

Based on the foregoing, if the Hungarian legislator held that coverage provided by independent lien should extend to interest and other charges in addition to the amount entered in the real estate register, then a provision to that effect would have to be explicitly stated in the text of the codification. In my opinion, the most practical solution would be for the Civil Code to grant this option to the parties as an alternative. By doing so, the parties could freely decide whether they consider the amount specified in the mortgage contract designed to establish independent lien (and accordingly in the real estate register) as a framework amount or as an amount that designates the principal only, given that the liened item may also be used to cover any related charges. Pursuant to the Civil Code, this option is already available to the parties in the case of accessory lien.

However, the wording of Section 5:100 of the Civil Code, which entered into effect on 01 October 2016, suggests that the 'certain amount' should be interpreted as a quasiframework amount, in excess of which independent lien does not cover any further claims.

14 The Mortgage Act also adopted the latter solution by expressly stipulating that interest and other ancillary services may also be entered in the land registry in addition to the principal amount of the land charge. Any interest payable on the land charge was subject to the rules applicable to interest on the mortgage debt [Section 82 (2)-(3) of the Mortgage Act]. Forward to Section 269 (1) of the former Civil Code the liened item could also be used to cover charges. That followed from a provision that allowed mortgaging the liened item without a personal claim. When that occurred, the lienor was entitled to seek satisfaction from nothing else but the liened item up to the amount specified in the mortgage contract and the related charges. The German BGB, too, includes interest and other charges within the scope of coverage ensured by Grundschuld [BGB 1191. § (1) Section]. Thus, the BGB allows the parties to obtain satisfaction from the liened item (real estate) against interest and other ancillary services on an alternative basis. 


\subsection{Mortgage contract in the case of independent lien}

Provisions of the Civil Code determining the compulsory formal elements of a mortgage contract are also applicable in the case of independent lien.

An important difference is that a mortgage contract only determines the amount of the secured claim in the case of independent lien but it does not have to include the legal grounds of the claim. The mortgage contract with independent lien does not have to include the legal relationship or legal grounds from which the secured claim arises or may arise. All this follows from the independence of independent lien of the secured claim. ${ }^{15}$

In the case of independent lien, the amount determined by the parties in the mortgage contract must also be entered in the real estate register. This is expressly stated in Section 5:100 (2) of the Civil Code, which provides that 'the contract forming the independent lien contains, apart from the description of the liened item, that amount determined, up to which satisfaction may be sought out of the liened'. Section 5:100 (2) of the Civil Code also makes it clear that the 'amount determined' indicates a framework or upper limit up to which the lienor may exercise its right to satisfaction.

This also answers the question whether the following provision can be applied to independent lien - in addition to stating its amount, a secured claim may be specified in any other way suitable for its identification. Given that a mortgage contract whereby independent lien is created does not include the secured claim, the parties cannot avail themselves of this option, which is ensured in Section 5:89 (5) of the Civil Code for independent lien. The amount indicated in a mortgage contract establishing independent lien must always be specified. The requirement for it to be specific is also met if the parties determine a certain percentage of the principal owed by the personal debtor, up to which the lienor is entitled to seek satisfaction from the liened item (e.g. X\% of the loan principal).

Provisions governing the specification of the liened item are also applicable to independent lien. Since, however, independent lien can only be established in the form of mortgage on real property, the liened item (real property) must, in all cases, be uniquely specified in the mortgage contract and in the consent to registration. This follows from Section 5:93 (3) of the Civil Code pursuant to which registration in the real estate register shall be effected based on the mortgage agreement or upon the lienee's consent to registration if the mortgage agreement or the consent to registration uniquely identifies the liened real property. Provisions in relation to consent to registration are also applicable to independent lien.

A further condition of establishing independent lien is for the lienee to be the owner of the real estate as indicated in the real estate register. It follows therefore that independent lien may not be established in respect of the future asset (real property). This, however, does not preclude cases where independent lien encumbers a piece of land used for constructing additional real property - as part of a capital expenditure project pursued for the purpose.

The parties can also specify in the mortgage contract the person entitled to exercise the lienor's right to satisfaction in the event of transfer. Frequently, the right to satisfaction against the lienee is exercised not by the new lienor but by a former lienor who had transferred the independent lien. This, however, is conditional on the new lienor transferring

15 The independent lien contract and the accessory lien contract are different because the independent lien contract does not contain a reference to the secured claim, instead, it provides for a threshold up to which satisfaction may be sought. See more in detail at Gárdos and Vékás (2016). 
the independent lien back to the original lienor. This usually happens when the new lienor acquiring independent lien during a refinancing arrangement refrains from recording the lien, and hence transferring the lien back does not require an additional entry in the register either. Under this refinancing arrangement, the new lienor may not exercise the right to satisfaction, other than exceptional circumstances typically in situations where the secured claim also transfered. In this case, the new lienor notifies the lienee or the personal debtor about the transfer of the new secured claim.

Also, nothing prevents the parties from including provisions on the termination of independent lien in the mortgage contract concluded to establish independent lien. When this occurs, the contract should contain a provision to the effect that independent lien will terminate by deletion from the real estate register. In relation to that, the provisions of Section 5:100 (8) of the Civil Code could be repeated. Doing so would be tantamount to providing in the mortgage contract that the lienee may, provided that the appropriate conditions exist, request re-registration of the independent lien or deletion from the real estate register.

The absence of the mortgage contract or the failure to conclude it, incurs the same legal consequences in the case of independent lien as in the case of accessory lien securing a debt: independent lien cannot be established in the absence of a mortgage contract. The statutory requirements relevant to the establishment of independent lien are not fulfilled in the absence of a mortgage contract and without the act of establishment no independent lien can be created.

\subsection{Security agreement}

\subsubsection{The nature of security agreements and their relationship with the mortgage contract}

In the case of independent lien, the parties must enter into another agreement, which is a security agreement, in addition to the mortgage contract. The security agreement is necessary due to the lack of statutory accessoriness. It plays a primary role in that it is designed, as a means of ensuring accessoriness under contract law, to settle issues not covered either by law or by the mortgage contract. These are provisions regulating primarily the accrual and manner of exercise of the right to satisfaction related to independent lien.

The question arises as to why the parties must enter into another agreement in addition to the mortgage contract. There are several practical arguments for this. Principally, mortgage contracts establishing independent lien must meet additional former requirements due to entry into the real estate register. However, it seemed unnecessary to extend these additional requirements to security agreements.

Another important argument for the separation of the two contracts was that if the parties only entered into a mortgage contract then, in the event of claim replacement the records in the real estate register should also be modified. In the case of independent lien, claim replacement is a wide-ranging option since independent lien does not terminate automatically upon the termination of the original claim. Therefore, the parties are free to use the same lien for securing another claim. If a change in the secured claim had to be recorded in the real estate register, the parties would unnecessarily spend money and time on such action. However, pursuant to the Civil Code, if the original secured claim terminates for whatever reason and the parties decide to use the surviving independent lien to secure another claim, all they will have to do is modify the security agreement or enter into a new one. That, however, does not affect recording in the real estate register or the mortgage 
contract and therefore does not call for modifying either records in the real estate register or the mortgage contract.

Based on the foregoing, specifying security agreements in the Civil Code as separate agreements under contract law offers primarily the advantage that a change in the amount of the secured claim, or the replacement of the claim itself, does not have to be recorded in the real estate register. ${ }^{16}$ The security agreement does not have to be filed with the real estate register authority. All this is conducive to developing independent lien into a truly flexible lien arrangement in practice.

Nothing prevents the parties from incorporating a mortgage contract and a security agreement in the same document. This can also be justified by the parties to both contract law agreements being the same because the security agreement is also made between the lienor and the lienee as is expressly provided by Section 5:100 (3) of the Civil Code. If the original purpose as security has been achieved i.e., the original claim determined in the security agreement has terminated, and the parties wish to use the surviving independent lien to secure another claim, then they must amend the security agreement. In this case, there is no need to amend the mortgage contract as it does not have to show the legal grounds of the claim. When the purpose of the security is modified, there is no need to change the records in the real estate register but, the lienor must be mindful that it can only enforce its right to satisfaction up to the amount indicated by the record in the register, should the claim amount indicated in the security agreement exceed that amount. Consequently, from the aspect of the scope of the lienor's right to satisfaction, independent lien is governed by the (original) amount indicated in the real estate register even in the case of a change in claim and the corresponding amendment of the security agreement.

In the case of incorporation in the same document, it is also possible for the parties to add the underlying transaction, typically a loan agreement, from which the secured claim originates. Notarisation required for what is known as 'immediate enforceability' typically covers all three contracts in the same notarial deed.

\subsubsection{Compulsory substantive elements of security agreements}

In addition to specifying the security agreement by name, the Civil Code also determines its compulsory substantive elements. The compulsory substantive elements of security agreements as determined in Section 5:100 (3) of the Civil Code are as follows:

- objective of the formation of the independent lien as being a security;

- conditions and scope of the accrual of the right to seek satisfaction;

- if the right to seek satisfaction accrues by termination, then also the manner of the exercise of termination and the notice period;

- other conditions of the accrual of the right to satisfaction such as objections that can be raised by the lienee.

The security agreement must specify security as the objective as independent lien can exclusively be established in order to secure a claim. The Civil Code states clearly and definitively that independent lien cannot be established for any other purpose, objective of the formation of the independent lien as being a security. The objective of the security is the

16 Some scholars opine that the security agreement does not meet the general expectations of contract law thus these should be viewed as property law instrument, emphasizing the mixed characteristics of the security agreement. See Gárdos and Vékás (2016). 
claim of money secured by the independent lien as referred to by Section 5:100 (6) of the Civil Code as 'claim which may be settled as per the security agreement'.

With independent lien, the secured claim must be a claim that can also be secured by way of an accessory lien. That means that Section 5:97 of the Civil Code also applies to independent lien. Therefore, as a general rule, the secured claim must be a claim of money and when a claim is non-pecuniary, the lien secures damages other claims of money arising from default. However, with independent lien, also in this latter (exceptional) case, it needs to be considered that the claim must be specified in the mortgage contract in a way to enable recording in the real estate register.

It has to be emphasised that the requirement to define the purpose as security in the security agreement must be interpreted in a flexible manner. That means it is not a requirement to determine the exact amount of the secured claim. It is sufficient to refer to the underlying legal relationship from which the secured claim originates e.g., to claims and related charges precisely defined in a specific loan agreement.

Based on the foregoing, the security agreement must be separated not only from the mortgage contract but also from the underlying contract. Application of the same level of detail in regulating the secured claim in the security agreement as in the underlying agreement is not a requirement. It must to be made clear is the legal grounds from which the secured claim originates and thus, in respect of the security agreement - as opposed to the mortgage contract - the principle of independence of legal grounds is not fulfilled, but nor does the requirement to specify the exact amount.

The parties can use the existing independent lien to secure another claim if the original secured claim has terminated for any reason or has decreased to an extent that the scope of the independent lien allows the parties to do so. There is no requirement that the independent lien must secure a new claim existing between the same parties.

The free transferability of independent lien, i.e., independent of the claim, enables the independent lien to be used by

- a new lienor and the original lienee (provided the lienee is also a personal debtor);

- the new lienor and a new personal debtor; and

- the original lienor and a new personal debtor

to secure a claim between them.

To avoid subsequent legal disputes arising from this arrangement, Section 5:100 (4) of the Civil Code also provides that 'with the transfer, the party acquiring the independent lien shall replace the transferor in the security agreement, to the extent of the transfer. The acquiring party may request the recording of their acquired right (...) in the real estate register.'

In the event of the final frustration of the purpose as security, the lienee may request the reregistration or deletion from the real estate register of the independent lien. Section 5:100 (8) of the Civil Code includes a special provision regarding this.

A further compulsory substantive element of a security agreement is the definition of conditions pertaining to the accrual of the lienor's right to satisfaction and also the scope thereof. The security agreement must also specify the scope of the right to satisfaction. In practice, it means specifying the claim amount and its charges, if any, to be satisfied under the security agreement. That is because the lienor has the right to satisfaction only up to that amount. There is no problem in cases where the claim to be satisfied under the security agreement does not exceed the amount indicated in the mortgage contract, and hence in the real estate register, up to which satisfaction can be sought based on the independent lien. The lienor's right to satisfaction in respect of the claim included in the 
security agreement is limited to the amount recorded in the real estate register. The scope of the right to satisfaction may not exceed the amount recorded in the register even if the claim set in the security agreement is higher.

The Civil Code stipulates in general that the conditions of exercising the right to seek satisfaction from the liened item must be laid down in the security agreement. This also means that if the parties wished to determine other conditions of exercising the right to satisfaction in addition to the foregoing, then they must do so in the security agreement. That can include the stipulation of objections lienee may raise. However, this will only have practical significance if the parties wish to furnish the lienee with a wider range of objections than those accruing to the personal debtor. It follows from the provision enshrined in Section 5:100 (6) of the Civil Code, which states that objections available to the personal debtor are also automatically available to the lienee. Under this express provision of the law, lienees can raise against the lienors under an independent lien the objections available to the obligor of the claim specified in the security agreement, i.e. the personal debtor. These objections do not have to be specified separately in the security agreement as their enforceability is not subject to that. Similarly, any objections available to the lienee based on other legal relationships with the lienor need not be determined in the security agreement either.

In respect of exercising the right to satisfaction, the parties are also free to agree that the lienee may seek satisfaction by way of the enforced simplified sale of the liened item. This is stipulated by Chapter XI of Act LIII of 1994 on Judicial Enforcement (Sections 204/B-204/H). In this case, however, the lowest selling price must also be stipulated in the security agreement.

Nothing prevents the parties from making subsequent additions to the security agreement between them even in respect of the conditions of exercising the right to satisfaction. This constitutes a contractual amendment just as when determining a new objective for the security. The general contract law provisions of the Civil Code must otherwise be applied to the amendment of the security agreements as appropriate. ${ }^{17}$

As a general principle, the Civil Code also states that the right to satisfaction can be exercised subject to the terms and conditions of the security agreement. Any application of the law to the contrary will constitute a breach of contract, which can ultimately give rise to a claim for damages in the lienee's favour.

\subsubsection{Other provisions related to security agreements}

A security agreement is an agreement under contract law to which provisions of the Contract Law Book of the Civil Code must also be applied. These rules also govern the conclusion, validity, effectiveness, amendment, breach and termination of a security agreement.

A security agreement must be made in writing. This, naturally, is also applicable to amendments to the security agreement. Hence, no agreement - verbal or by way of acceptance by conduct - may result in the creation or modification of a security agreement.

However, no further formal requirements are prescribed either by the Civil Code or other legislation. The validity of a security agreement is, therefore, not conditional on either a lawyer's or a legal counsel's countersignature or on notarization. However, the latter can be relevant from the aspect of immediate enforceability.

17 On the amendment of the security agreement see Gárdos and Vékás (2016). 
The question is what legal consequences arise from the parties' failure to enter into a security agreement. Establishing an independent lien requires a mortgage contract. The absence of a security agreement does not affect the creation of independent lien, provided that the parties have concluded a valid mortgage contract. Therefore, the legal consequences of the absence of a security agreement will be different from the legal consequences arising from the absence of a mortgage contract. In particular, they include first of all the lienor's inability to seek satisfaction under the independent lien. ${ }^{18}$ Consequently, the existence of a security agreement plays a key role for the lienor since lien without the right to satisfaction is unlikely to have any real collateral value.

Another legal consequence is that Section 5:100 (8) of the civil Code also enables the lienee to delete the independent lien from the real estate register or request reregistration (in favour of another financial institution or itself), if no security agreement exists.

Full invalidity leads to a similar situation to that arising when a security agreement is not even concluded, i.e. the lienor is not entitled to seek satisfaction if full validity occurs. For example, a security agreement is invalid when the objective of the security (namely the claim to be satisfied under the security agreement) included therein does not exist due to the invalidity of the underlying transaction from which the claim constituting the purpose as security originates. With an accessory lien, however, it is the mortgage contract that is invalid in such a case. For independent lien, the situation is different as the mortgage contract establishing the independent lien will not be directly affected by the claim determined in the security agreement or by the invalidity of the underlying transaction. In the case of independent lien, it is the security agreement that will be rendered invalid as a result of the invalidity of the underlying transaction and of the claim originating therefrom. Hence, the lienor will not be entitled to seek satisfaction and the lienor may request the deletion of the independent lien or may have it reregistered to another financial institution. However, the reregistration of independent lien will only make sense if the parties enter into another - this time valid - security agreement.

\subsection{Transfer of independent lien}

One of the key characteristics and great advantages of independent lien is that it can also be transferred without the secured claim, ${ }^{19}$ creating its negotiability. It also follows from the free transferability of independent lien that this arrangement can be applied to cases when the independent lien is acquired by a new lienor who wishes to transfer it to a third party financial institution. This is the great advantage of independent lien as a tool for boosting the refinancing market. Separated lien did not lend itself to multiple transfers of this kind.

The lienee's position does not become any more onerous as a result of the transfer of independent lien. Although the transfer serves to secure a claim between the original lienor and the new lienor e.g. for the purpose of refinancing, it does not affect the extent of the lienee's liability. That is because the lienee is only required to tolerate satisfaction by the lienor from the liened item up to the claim amount determined in the security agreement but not in excess of the amount indicated in the mortgage contract and in the real estate register.

18 For a supporting argument see Gárdos and Vékás (2016).

19 The Hungarian Civil Code does not contain a separate provision on the transferring of the independent lien. For these, the general transferring of rights provisions should be applied. See Gárdos and Vékás (2016). 
The transfer of independent lien does not influence this at all since the claim between the two lienors does not become a part of the claim determined in the security agreement.

In addition, the lienee can raise the same objections vis-à-vis the new lienor of the independent lien that are available to the personal debtor in the underlying transaction. Based on this, the lienee can also cite vis-à-vis the new lienor acquiring the independent lien that the claim specified in the security agreement has already been fulfilled. All this precludes situations where a lienee could be forced to perform twice.

\subsection{Exercising the right to objection}

The former Civil Code increased the negotiability of the independent lien through the institution of objection limitation. Thus, the free transfer of independent lien without a connected claim deprived the lienee of the right to raise objections with reference to the underlying legal relationship against the new lienor acquiring the independent lien in good faith and for a consideration. In legal literature, this is known as the institution of objection limitation, which originates from bill of exchange law. As Hungarian private law did not enable the securitisation of independent lien after the political changeover, this legal institution originating from security law exposed lienees (who are also personal debtors) to the risk of being forced to bear double liability.

In order to protect lienees as owners, the CCAA abolished objection limitation and thus the risk of double liability was removed. In relation to this issue, Section 5:100 (6) of the Civil Code states that 'the lienee may refer against the obligee of the independent lien at any time also to those objections which the obligor of the obligation determined under the security agreement is entitled to raise'. This means that the lienee can, by operation of law, also raise the same objections that are available to the personal debtor. Therefore, this right is not subject to whether the parties agreed on these objections in the security agreement. The lienee is entitled to raise objections available to the personal debtor even if such provisions are not included in the contract. In this respect, independent lien is not different from accessory lien - reregulated independent lien is of an accessory nature as regards raising objections. Therefore, accessoriness linked to the enforcement of rights also exists with independent lien.

Among the statutory objections available to the lienee, the objection to the fulfilment of the secured claim is the most relevant. However, the lienee can also invoke other reasons for termination and base its objection citing the invalidity of the secured claim on grounds of the invalidity of the underlying legal relationship from which it originates.

In addition to citing objections available to the personal debtor, the lienee may also invoke objections available to its own person vis-à-vis the lienor. These can originate from the independent lien itself, e.g., a lien has not been created. Objections directly related to the independent lien are rights in rem by nature. However, the lienee may also raise objections under contract law available to it forward to its other legal relationships with the lienor. They include objections related to the right to offset which the lienee can enforce based on any pecuniary claim against the lienor. On this basis, the lienee under the independent lien, just as the lienee of the accessory lien, is entitled to offset its pecuniary claim vis-à-vis the lienor against an amount up to which the lienor is entitled to seek satisfaction from the liened item. ${ }^{20}$

20 Connected with this is the question of whether the lienee is entitled to offset the amount of a counterclaim that is due to the personal debtor. As regards suretyship, there are special provisions on this matter in Section 6:417 (2) of the Civil Code. Formerly, Section 44 (1) of the Mortgage Act 
Naturally, nothing prevents the parties from specifying these objections in the security agreement but this is not a prerequisite for raising such objections.

Regulating the enforcement of objections is an area where reregulated independent lien differs to the greatest extent from the former Civil Code and from the Mortgage Act of 1927. Objection limitation was abolished to protect the lienee. That, however, was also conducive to lending an accessory character to reregulated independent lien as far as raising objections are concerned. This is an important instrument for protecting owners, which, however, does not significantly prejudice the advantages attached to independent lien or the compliance of reregulated independent lien with the CRR regulation. ${ }^{21}$

\subsection{Protection of the personal debtor}

Revoking the objection limitation, allowing objections, protects the lienee whilst at the same time, it was also necessary to take increased care of protection of the personal debtor.

The issue of protecting the personal debtor can primarily arise if the lienee and the personal debtor are not the same person and the original lienor has transferred its independent lien. In this case, the possibility exists that the original lienor, who is also the obligee (creditor) of the legal relationship underlying the secured claim, demands performance from the personal debtor while the independent lien's new lienor turns against the lienee. Although the lienee can invoke objections available to the personal debtor now that the objection limitation is abolished, it should be stated that the personal debtor may not be forced to perform either, if the lienee had already performed or tolerated the exercise by the lienor of its right to satisfaction from the liened item. To this end, Section 5:100 (6) of the Civil Code also stipulates that 'the amount of the claim which may be settled as per the security agreement is reduced by the purchase price proceeds accrued in the course of the exercise of the right to seek satisfaction'.

On this basis, therefore, if the lienor of the independent lien has, by reason of its right to satisfaction, already received reimbursement from the lienee, the purchase price received in this process will reduce the debt owed by the personal debtor. If the purchase price thus received is equal to the amount of the original claim, i.e. the claim that can be demanded under the security agreement, the debt owed by the personal debtor will cease to exist. If, however, the purchase price received is less than the debt owed by the personal debtor, only the difference can be demanded from the personal debtor. Naturally, the lienee will also be entitled to reimbursement vis-à-vis the personal debtor, in accordance with Section 5:142 (2) of the Civil Code.

That prevents a situation where the acquirer of the independent lien and the original lienor collect the same debt from the lienee and from the personal debtor, respectively. The lienors can only claim reimbursement once and they must settle the consequences thereof in the legal relationship between them. At the same time, neither lienor's interests are violated, provided that the independent lien has been transferred for a consideration. However, in the

included similar provisions in respect of mortgages to allow the mortgage holder to offset all those amounts - in addition to its own counterclaims - vis-à-vis the mortgage creditor which the personal debtor was entitled to offset. However, neither the Civil Code, nor other legislation under our current law contains provisions to this effect and therefore, in our opinion, it is not possible for the lienee in rem to offset vis-à-vis the lienor such amounts of counterclaims as are due to the personal debtor. For a differing opinion see Gárdos and Vékás (2016).

21 Gárdos and Vékás (2016). 
event of free transfer, the original lienor must reckon with the prospect of losing entitlement to the secured claim or a part thereof since it has already been collected by the new lienor from the lienee.

Naturally, it can also happen that the personal debtor, unaware that the amount of the secured claim has already been collected from the lienee, will pay voluntarily. This payment, however, can be recovered subsequently, by invoking the previously referenced Civil Code provision, from the original lienor who transferred the independent lien and was the creditor of the performing personal debtor on the basis of the underlying legal relationship. However, the lienee's claim for reimbursement against the personal debtor also exists if the personal debtor has made a full payment to the original lienor and has not been able to enforce its related claim for reimbursement. Therefore, it is recommended to ascertain prior to performance whether the lienor has already exercised its right to satisfaction vis-à-vis the lienee and, if so, to what extent the debt has been paid to the lienor. In this respect, it is also appropriate to admit that the lienor of the independent lien cannot invoke bank secrecy when imparting such information.

Based on the foregoing, the Civil Code excludes the risk of double performance by both of the lienee and the personal debtor because neither can be obliged to perform twice in respect of the debt specified in the security agreement or to tolerate satisfaction from the liened item once payment has been made. ${ }^{22}$

\subsection{Accrual of the right to satisfaction upon termination}

In the absence of accessoriness in the case of independent lien, the falling due of the secured claim and failure to perform payment do not automatically result in the accrual of the lienor's right to satisfaction. This requires some additional legal act which, based on experience relating to the domestic and international regulation of non-accessory lien, is usually termination.

Under the former private law, Section 83 of the Mortgage Act provided for termination; Section 1193 of the BGB also contains special provisions on termination and Section 269 (2) of the former Civil Code regulated termination under separate provisions.

The amended Civil Code has complicated matters in that it governs security agreements under special provisions within the scope of independent lien. The following cases of termination must be distinguished:

- termination of the security agreement;

- termination of the independent lien;

- termination of the underlying legal relationship.

Termination of the security agreement results in the termination of the agreement, in which case, however, the lienor will not be able to exercise its right to satisfaction. This is one of the legal consequences of the absence of a security agreement. The Civil Code does not lay down separate provisions on termination of the security agreement but nothing prevents the parties from including separate provisions about this matter in the security agreement.

By contrast, the Civil Code regulates the termination of the independent lien separately. Pursuant to Section 5:100 (5) of the Civil Code, independent lien may be terminated by

22 The critical viewpoints of the legal literature acknowledge the fact that this provision does restrict the risk of double performance, however, the wording of the provision is regarded incorrect. See Gárdos and Vékás (2016). 
both the lienor and the lienee. Section 5:100 (3) of the Civil Code also clearly determines the legal consequence thereof: the right to satisfaction accrues upon termination. Pursuant to Section 5:100 (3) of the Civil Code, if the right to satisfaction accrues by way of termination then the method of exercising the right to terminate and the notice period must be determined in the security agreement. This is also confirmed by amended Section 5:126 (2) of the Civil Code, pursuant to which the lienor's right to satisfaction, unless otherwise agreed by the parties in the security agreement, will accrue upon termination of the independent lien or upon expiry of notice period.

Thus, termination of the independent lien results in the accrual of the lienor's right to satisfaction. This happens upon expiry of the notice period. In accordance with the dispositive rule of the Civil Code, the notice period, unless otherwise agreed by the parties, is 6 months. In this regard, it has to emphasise that specifying a notice period which is either too short or long is inconsistent with the requirement to exercise a right for its intended purpose. If the notice period is stipulated in the lienor's previously existing general terms of contract, then the fairness of such stipulation can also be made subject to scrutiny provided, naturally, that the given stipulation has also become part of the agreement.

Section 5:100 (5) of the Civil Code provides, as an important safeguard, that if the right to satisfaction accrues by reason of termination then its exclusion will be null and void. This means that if the parties select another manner for the right to satisfaction to accrue, e.g., if they link it to a particular condition or date, then termination can be excluded as a matter of course. In that case, the security agreement is not likely to contain provisions in respect of termination of the independent lien anyway. If, however, the parties have not linked the accrual of the right to satisfaction to another legal act, then the right to terminate is available to both the lienor and the lienee by operation of law. To regulate the latter case, the Civil Code provides that the exclusion of the right to terminate will be null and void under such circumstances, as the exclusion of the right to terminate would lead to an undesirable outcome whereby the lienor's right to satisfaction would never accrue in the absence of a legal act to produce that legal consequence.

Ensuring the right to terminate is critically important for both parties. If the right to terminate only accrued to the lienor who refrained from exercising it, a situation could arise whereby the lienee would never be relieved of this burden in rem. On the other hand, the lienee may also find it important to ensure that the lienor is satisfied as soon as possible, e.g., they wish to replace the existing loan with one on more favourable terms.

Regulating the notice period is equally important for both parties. For the lienee, it provides a safeguard that its liability covered by the liened item will not fall due immediately. Conversely, an appropriate notice period is also essential for the lienor as it will provide sufficient time for performing the necessary replacement of independent liens that serve to back mortgage bonds. ${ }^{23}$

While, due to the absence of accessoriness, the Civil Code lays down special provisions in respect of the accrual of the right to satisfaction stemming from the independent lien, there is no difference between an accessory lien securing a claim and an independent lien in terms the content of the right to satisfaction. Accordingly, in exercising its right to satisfaction the lienor under the independent lien enjoys the same rights and is bound by the same obligations as the lienor of an accessory lien.

23 On the termination of the independent lien contract see Gárdos and Vékás (2016). 
The termination of the underlying legal relationship must be distinguished from terminating the independent lien and the security agreement. As a rule, terminating the underlying legal relationship does not affect the independent lien. However, the parties may also link the accrual of the right to satisfaction under an independent lien to the termination of the underlying relationship. In this case, the termination of the underlying relationship alone is sufficient for the right to satisfaction to accrue and there will be no need in this case to terminate the independent lien.

\subsection{Reregistration and deregistration of the independent lien}

In order to make the independent lien more flexible, Section 5:100 (8) of the Civil Code offers the lienee several new options. The common theme in these options is that the lienee can rely on them if the original purpose of the independent lien to serve as a security ceases to exist for some reason. Pursuant to the cited provision of the Civil Code, that can happen in the following cases:

- if the security agreement has not been concluded;

- if the purpose of establishing the independent lien as indicated in the security agreement has been finally frustrated;

- if the security agreement has terminated;

- if the claim to be satisfied from the liened item - including a claim for reimbursement - as indicated in the security agreement has terminated;

- if any reason or condition stipulated in the security agreement and resulting in termination of the independent lien has occurred.

In such cases, the lienor has an obligation to consent, at the lienee's written request, to

a) entering the lienee as the lienor of the independent lien in the real estate register; or

b) entering the financial institution designated by it as lienor in the real estate register; or

c) deregistering the independent lien from the real estate register.

Consequently, the lienee will be entitled to one of the following three options in the cases described above:

- it may request recording in the real estate register another financial institution it designates as the new lienor of the independent lien;

- it can request recording its own person in the real estate register as the new lienor of the independent lien;

- it can request deregistration of the independent lien from the real estate register.

Based on the foregoing, there are two possible cases of reregistering the independent lien:

- reregistering the independent lien in favour of another financial institution;

- reregistering the independent lien in favour of the lienee as owner.

The latter creates an owner's independent lien, which is a new legal institution under Hungarian Private Law. ${ }^{24}$ An owner's lien is also recognised by the provisions of Sections 5:142 (2) and (3). This designation, however, is not used by the Civil Code. An owner's independent lien, as regulated in Section 5:100 (8) of the Civil Code, is a special category in that it exists without any actual claim and therefore there is no demand for reimbursement either as would be secured by an owner's lien. Accordingly, owner's independent lien is similar to a claimless ranking right. Naturally, the three types of owner's lien may not exist simultaneously but their relationship relative to each other requires further clarification.

24 For a supporting argument see Gárdos and Vékás (2016). 
Owner's independent lien can facilitate the lienee's raising a new loan. As far as its financial function is concerned, it is a legal institution similar to securing a ranking position in advance or to disposing over a terminated ranking position.

\section{SUMMARY}

In my opinion, reregulated independent lien is an appropriate legal arrangement which responds to the economic needs calling for the facilitation of lending and the stimulation of the Hungarian mortgage bond market. That given, the application of the independent lien also offers much greater opportunities, e.g., the potential to combine it with the institution of fiduciary asset management, and thereby offer new refinancing techniques to the Hungarian banking sector. ${ }^{25}$

\section{LITERATURE}

Barát, Mihály, 'Három jelzálogbank jöhet' (Three mortgage banks may come) Világgazdaság (2015) 16 August, http://www.vg.hu/penzugy/harom-jelzalogbank-johet-455693 accessed 31 July 2017.

Bodzási, Balázs, 'Javaslat az önálló zálogjog újraszabályozására' (A proposal for the recodification of the non-accessory mortgage) in Gárdos, Péter (ed), Tanulmányok a fiduciarius biztositékok köréböl (HVG-ORAC 2010) 365-98.

Bodzási, Balázs, 'A fiduciárius hitelbiztosítékok tilalma' (The prohibition of fiduciary securities) in Bodzási, Balázs (ed), Hitelbiztositékok (HVG-ORAC Budapest, 2016a) 37-44.

Bodzási, Balázs, 'Az önálló zálogjog' (The non-accessory mortgage) in: Bodzási, Balázs (eds), Hitelbiztositékok (HVG-ORAC 2016b) 766-76.

Bodzási, Balázs, 'Entwicklung der Regelungen zum ungarischen Pfandrecht unter besonderer Berücksichtigung des nicht akzessorischen Pfandrechts.' (2016c) 1 Zeitschrift für Europäisches 218-37.

Clemente, Clemens, Recht der Sicherungsgrundschuld (RWS Verlag, Köln, 1999).

Csizmazia, Norbert, ‘A zálogjog és Ockham borotvája' (Liens and Ockham’s Razor) (2016) 5 Polgári Jog 31 .

Gaberdiel, Heinz and Gladenbeck, Martin, Kreditsicherung durch Grundschulden' (8 ${ }^{\text {th }}$ ed, Erich Schmidt Verlag 2008).

Gárdos, István and Csizmazia, Norbert, 'Az önálló zálogjog kodifikációs szempontból' (The nonaccessory mortgage from the point of view of the codification) in Gárdos, Péter (ed), Tanulmányok a fiduciarius biztositékok köréböl (HVG-ORAC 2010) 399-422.

Gárdos, Péter, 'Észrevételek a Ptk. tervezett módosításának egyes zálogjogi és kötelmi jogi rendelkezéseihez' (Some remarks on the project of the Hungarian Civil Code on mortgage and law of obligations) (2016) 5 Polgári Jog.

Gárdos, Péter - Vékás, Lajos (eds), Kommentár a Polgári Törvénykönyvről szóló 2013. évi V. törvényhez (Commentary on the Hungarian Civil Code) Ptk. 5:100. § (online version - manuscript closed on 17 November 2016).

Handkommentar zum Schweizer Privatrecht (Amstutz, Marc et al eds, Schulthess 2007).

Wehrens, Hans, 'Der schweizer Schuldbrief und die deutsche Briefgrundschuld. Ein Rechtsvergleich als Basis für eine zukünftige Eurohypothek' (1988) 7 Österreichische Notariatszeitung, 181-91.

25 The potential to use fiduciary asset management for bank refinancing purposes is also discussed by Norbert Csizmazia. See Csizmazia (2016) 5, 31 . 